\title{
SÕNASEMANTIKA JA TEKSTI MÕISTMINE PÕHIKOOLI ESIMESES JA TEISES KOOLIASTMES
}

\author{
Krista Uibu, Maile Timm
}

Ülevaade. Sõnasemantika ehk sõna tähenduse tundmine on oluline tervikteksti sisu mõistmisel. Kui sõnade tähendus ei kinnistu, võib teksti mõistmine kujuneda õpilastele probleemiks kõigis kooliastmetes. Käesoleva pikiuurimuse eesmärk oli välja selgitada, mil määral muutub sõnatähenduse tundmine ja teksti mõistmine põhikooli esimeses ja teises kooliastmes. Artiklis analüüsitakse 3.-5. klassi õpilaste sõnatähenduse ning kahe raskusastmega tekstimõistmise ülesannete sooritust. Uuringus osales 508 õpilast (267 tüdrukut ja 241 poissi) 30 Eesti üldhariduskoolist. Selgus, et teksti mõistmine oli parem õpilastel, kes tundsid paremini erinevate sõnade tähendust. Soolises võrdluses edestasid tüdrukud poisse kõigil kolmel aastal sõnatähenduse tundmises ja teksti mõistmise keerukamas ülesandes, mis eeldas head info integreerimise oskust. Tüdrukud tundsid poistest paremini ka nende sõnade tähendust, mida nad olid varem õppinud. Et toetada õpilaste semantilist pädevust ja teksti mõistmist, on oluline arvestada nende arengulist eripära ning pakkuda lugemiseks võimetele ja huvidele vastavaid tekste.*

Võtmesõnad: sõnasemantika, teksti mõistmine, soolised erinevused, pikiuurimus, eesti keel

\section{Sissejuhatus}

Teksti mõistmine on keerukas kognitiivne protsess (Cain jt 2004), mis on seotud sõnasemantika, sh sõnade tähendussuhete mõistmisega (Häkkinen 2007). See hõlmab kõike alates üksikute sõnade kodeerimisest kuni tervikteksti sisu mõistmiseni (Kabilan jt 2010). Teksti mõistmise ja sõnavara arendamine on olulisimaid ülesandeid põhikoolis (Põhikooli riiklik õppekava 2010). Nii on esimese kooliastme eesmärk lugemistehnikate omandamine ning sõnatähenduse, lause ja tervikteksti

* Uurimust on toetanud Haridus- ja Teadusministeeriumi grant nr 3-2/TA5966 "Eesti põhikooli efektiivsus". 
sisu mõistmine. Teises kooliastmes on põhirõhk eakohastest tekstidest arusaamisel ja tekstist vajaliku teabe leidmisel (Põhikooli riiklik õppekava 2010). Kui laps mõistab sõnade tähendust, siis saab ta tõenäoliselt aru ka lausetest ja tervikteksti mõttest. Samas tekitab sõnasemantika paljudele õpilastele probleeme, sest erinevatel põhjustel (nt ajanappus, tähelepanematus, teksti keerukus) ei pruugi uued sõnad kinnistuda ning nende tähendus jääb arusaamatuks. Seepärast on oluline märgata raskusi põhjustavaid sõnu (Soodla jt 2013) ja pühendada nende kinnistamisele piisavalt aega.

Teksti mõistmise ja sõnavara tundmise uurimustest on selgunud, et õpilastel esineb raskusi eakohastest tekstidest arusaamisega, arendamist vajab sõnasemantika (Henno jt 2007, Pandis 2002, Puksand jt 2010). Samas puuduvad pikiuurimused õpilaste sõnatähenduse tundmisest ja seostest teksti mõistmisega. Käesoleva uurimuse eesmärk oli välja selgitada pikaajalised muutused põhikooli esimese ja teise kooliastme õpilaste sõnatähenduse tundmises ning seosed sõnatähenduse ja ilukirjandusliku teksti mõistmise vahel.

\section{Sõnasemantika ja teksti mõistmise areng}

\subsection{Keele ja sõnatähenduse omandamine}

Noam Chomsky (1965) käsitluse järgi on keele omandamise süsteem inimesel kaasa sündinud ja keel omandatakse kuulmise abil. Seevastu kognitiivpsühholoogias valitseb arvamus, et lapsed ei omanda keelt mitte loomupäraselt, vaid õpivad seda kasutama kogemuslikult (Tomasello jt 1997). Saxtoni (2010) järgi tähendab keele kogemuslik õppimine individuaalse kõne kujunemist. Oluline periood emakeele arengus on nn kriitiline periood, mis algab 6. eluaastast ja kestab varase puberteedieani (umbes 12. eluaastani). Maksimaalse tulemuse saavutamiseks tuleks teha keele omandamisega tööd selleks ettenähtud ajal, sest pärast seda ei ole võimalik keelt täielikult omandada (Saxton 2010). Uurimusi keele õppimise kriitilisest perioodist on ka teistelt teadlastelt (Lenneberg 1967, Mayberry 1993, Meisel 2008), kes on leidnud, et esmatähtis on arendada sõnavara, mille kaudu laps õpib nii verbaalset suhtlemist kui ka lugemist. Sõnade õppimise tasandil analüüsib õppija igat sõna täht-tähelt, iga täht on eraldi üksus ning need kokku moodustavad uue tähendusega terviksõna (Schroeder 2011). Uut sõna korrates ja analüüsides kinnistatakse sõna tähendus ning see liigub lühiajalisest mälust edasi pikaajalisse mällu (Tulving, Madigan 1970).

Nii Zhang jt (2008) kui ka Prado ja Plourde (2011) on leidnud, et sõnavara omandatakse etapi viisi. Esimeses etapis toimub tajutav sõnatöötlus ehk sõna seostatakse reaalse eluga. Näiteks, sõna kullerkupp puhul soovitatakse kasutada visuaalset materjali (pildikaarte, fotosid, videoid), mille abil tekivad lapsel kiiremini seosed ja mälupildid. Teises, liigendamise etapis kujuneb õppijal reaalne seos sõna ja objekti vahel (vt ka Tulving, Madigan 1970: 437-484), nt kullerkupp näeb välja selline nagu pildikaardil, ta on kollast värvi (õpetaja räägib juurde, et lill õitseb kevadel). Lapsel on tekkinud õpitud sõna kohta tajupildid ning need on kandunud üle reaalsesse ellu. Kolmandas etapis oskab laps õpitud sõna juba sobivas kontekstis kasutada, nt vestlusel kevadlilledest teab ta, et kullerkupp on 
kollane kevadlill. Kui kõik need kolm etappi on läbitud, on suur tõenäosus, et õpitu kinnistub (Zhang jt 2008).

On leitud, et sõnaliigiti on sõnade omandamine erinev. Kuna sõna on abstraktne mõiste, siis enne tähenduse andmist sõnale peab õppija selle enda jaoks kategoriseerima (Bloem, La Heij 2003, Caramazza 1997), nt kullerkupp on lill, nimisõna. Kõige lihtsam on omandada konkreetse tähendusega nimisõnu, sest neile saab osutada otse (nt lill, vihmavari, laud). Keerulisem ja aeganõudvam on omandada abstraktse tähendusega nimisõnu (nt kurbus, lein, õnn), mida pole võimalik otseselt näha ega katsuda (Hirsh-Pasek, Golinkoff 2006). Veelgi keerukam on tegu- ja omadussõnadega (Imai jt 2005), sest sõnale tähenduse andmine tähendab erinevate kasutuskontekstide ühendamist ja laiendamist (Cruse 2004). Lisaks vajab laps tegu- ja omadussõnade puhul mitmekordset kogemust, enne kui ta sõna tähenduse omandab (Saxton 2010).

Ainuüksi sõnade tähenduse mõistmisest aga ei piisa, et tekstist tervikuna aru saada. Sõnade produtseerimises mängivad ühtmoodi olulist rolli nii semantika, süntaks kui ka sõnavara, kusjuures keeleõppes toimivad need tasandid järjestikkuse põhimõttel ehk kõigepealt tehakse keeleõppes tööd sõna tähendusega (semantiline tasand), seejärel lauseõpetusega (süntaks) ja viimasena sõnavara avardamisega (leksikaalne tasand) (Bock 1982, Butterworth 1989, Caramazza 1997). Et tekstist aru saada, on oluline mõista sõna lause tasandil ja tajuda lauset kui tervikut. Samuti peab lugeja mõistma, kuidas laused on omavahel seotud ja kuidas nad moodustavad tervikteksti (Karlep 2003).

\subsubsection{Eelteadmiste tähtsus teksti mõistmisel ja uue sõnavara omandamisel}

Begeny ja Silber (2006) leidsid oma uurimuses, et paljude algklassiõpilaste jaoks tekitab teksti mõistmine raskusi. Ka teised uurijad (Masterson, Apel 2006, Schroeder 2011) on märkinud, et teksti sisu mõistmine on lugeja jaoks keeruline protsess, sest tekstides esinevad sõnad on sageli erineva raskusastmega ning neid võidakse mõista erinevalt. Nii võib lihtsamate sõnade omandamisele kuluda mitu korda vähem aega kui keerukamate sõnade õppimisele. Tekkida võib olukord, kus laps loeb justkui lünkteksti: ta mõistab tuttavaid ja kiiremini õpitavaid sõnu, kuid raskemad sõnad jäävad talle arusaamatuks. Varem omandatud sõnavaral ja eelteadmistel on seega tähtis ülesanne (Broek, Espin 2012, Soalt 2005). Eelteadmised aitavad luua seoseid uue ja tuttava info vahel, lihtsustades võõra teksti mõistmist (Prado, Plourde 2011, Primor jt 2011, Schroeder 2011).

Eason jt (2012) tõdevad, et lapsed, kellel on minimaalne kokkupuude uue sõnavaraga, ei mõista täielikult uue teksti tähendust. Tundmatute sõnade mõistmise juures on tähtis ka see, et sõna, mida õppija kuuleb, oleks tema jaoks tuttava kõlaga (fonoloogiline teadlikkus) (Begeny, Silber 2006, Pečjakjt 2011). Samuti aitab tähenduse mõistmisele kaasa see, kui õpitud sõnu asetatakse erinevasse konteksti (Cruse 2004). Nii saab sõnade tähendus kiiremini selgeks võrreldes sellega, kui sõnu kasutatakse vaid ühes kontekstis.

Sama oluline kui tundmatute sõnade märkamine tekstis on nende esitamise viis (Hall, Sabey 2007). Uute sõnade selgitus ja kasutus peavad olema piisavalt 
sagedased (8-10 tähenduslikku väljendit uue sõnaga), külluslikud (sõnale leitakse sünonüüme, paronüüme ja antonüüme) ning avarad (sõna kasutatakse erinevas kontekstis). Sõnade täpse vaste teadmine lisab lastele enesekindlust ja huvi lugemispala vastu (Wise jt 2010). See omakorda seostub eduelamusega, mis innustab edasi lugema ning uurima. Bray ja Barron (2003) juhivad aga tähelepanu sellele, et laste jaoks huvitavate tekstide leidmine võib osutuda küllaltki keeruliseks.

\subsubsection{Teksti mõistmise arendamine põhikoolis}

Lugemise peamine eesmärk on arendada teksti mõistmise oskust (Primor jt 2011). Lugeja ülesanne on anda sõnadele ja tekstile tähendus vastavalt kogemustele ja omandatud sõnavara mahule (Puksand jt 2010). Nii saab arendada ka abstraktsemat mõtlemist ja keerukamate seoste mõistmist.

Põhikooli esimeses kooliastmes (1.-3. klassis) on eesti keel integreeritud õppeaine, mis hõlmab nii emakeelt kui ka kirjandust. Peamine eesmärk on lugemistehnikate arendamine ja õpitud tekstide mõistmine. Tekstid esimeses kooliastmes on lihtsad ja selgelt sõnastatud (Uibu, Voltein 2010). 4.-6. klassis on eesti keel ja kirjandus eraldi õppeained, kus olulisel kohal on info integreerimise, analüüsi- ja järeldamisoskuse arendamine, mida aitab saavutada keerukamate tekstide lugemine (Põhikooli riiklik õppekava 2010). Tekstid muutuvad tähendusrikkamaks, laste sõnavara avardub. Kuigi teksti mõistmise eesmärgid esimeses ja teises kooliastmes on mõnevõrra erinevad, on need omavahel hierarhilises seoses (Zhang jt 2008). Seega kui laps ei ole esimeses kooliastmes omandanud elementaarset lugemisoskust, siis ei saa temalt eeldada ka abstraktsema teksti sisu mõtestamist - tal puuduvad selleks vajalikud eeloskused ja ettevalmistus.

\subsection{Ilukirjandusliku teksti mõistmine}

Tekstiliigil võib olla määrav tähtsus, kui hästi laps mõistab teksti sisu (Eason jt 2012). Kõige üldisemalt võib tekstid, millega õpilased põhikooli esimeses ja teises kooliastmes kokku puutuvad, jaotada teabe- ehk õppekirjanduseks ja ilukirjanduseks. Ilukirjanduslikud tekstid on hea võimalus õpetada lapsele juba varases eas teksti sidusust ja loogilisust, mis aitavad mõista loetu sisu (Chun 2009). Kui tekst on kirjutatud lihtminevikus, jutustavas vormis, kasutatud on igapäevaseid väljendeid ja tegelaskujusid, hõlbustab see teksti mõistmist. Kasutatakse ka ilukirjanduslikke väljamõeldisi, mis on lastele tuttavad. Ilukirjanduslik tekst pakub sageli elamust, milles võib peituda ka kasvatuslik moment. Sidus tekst võib sisaldada uusi sõnu ja väljendeid, mis kuuluvad konteksti ning mida on lastel seetõttu kergem mõista ja omandada.

Põhikooli teises kooliastmes muutuvad ilukirjanduslikud tekstid mahukamaks. Oluline on arendada lapse fantaasiat ja loogilist mõtlemist (Soalt 2005), samuti oskust kirjeldada ja analüüsida sündmusi ja tegelaskujusid, liigendada teksti ning eristada peamõtet. Lisaks seostatakse olemasolevad teadmised uutega ja kujundatakse arusaamu (Block, Pressley 2002).

Üks probleeme ilukirjandusliku tekstiga töötamisel on selle keelekasutus (Müürsepp 1986). Autor peab tabama lugeja sõnavara mahtu ja teksti mõistmise 
võimet. Sihtrühmaks olevad lapsed peavad suutma loetut haarata, kuid tekst peab neile ka midagi uut pakkuma. Mõningatel juhtudel on vaja kasutada varasemaid teadmisi, et täita lünki ja sõnastada tervikmõte (Eason jt 2012, Müürsepp 1986).

\subsection{Soolised erinevused teksti mõistmises}

Poisid ja tüdrukud erinevad teksti mõistmise poolest üksteisest. Põhikoolis on tüdrukute vaimne areng poistest kiirem (Logan, Johnston 2010, Ning jt 2010, Prado, Plourde 2011), see mõjutab muu hulgas nende võimet tekstist aru saada (Bray, Barron 2003). Räty jt (2004) leidsid, et humanitaarainetes, eelkõige keeleõppes, edestavad tüdrukud algklassides poisse. Kelley ja Deckeri (2009) sõnul peavad tüdrukud alates teisest kooliastmest lugemisoskust vajalikumaks kui poisid ning loevad rohkem koolivälist kirjandust. See omakorda avaldab positiivset mõju sellele, kuidas tüdrukud teksti mõistavad (Puksand jt 2010). Ka rahvusvahelise PISA funktsionaalse lugemise testidest on selgunud, et tüdrukud saavad teksti mõistmise ülesannetes paremaid tulemusi kui poisid - vahe on võrdsustatav isegi terve õppeaastaga (OECD 2009, 2013).

Kuigi tüdrukute lugemisoskuse areng on kiirem, on võimalik poisse tüdrukutega samale tasemele viia, kuid see nõuab järjepidevat tööd (Bruemmer 2006, Corthals 2010). Selleks on vaja õpetaja teadlikku suunamist, kannatlikkust ja aega, et loetud pala põhjalikult analüüsida ja ümber jutustada ning moodustada teksti kohta küsimusi. Oluline on suunata poisse süvenema loetusse, mitte anda neile tavapäraseid ülesandeid. Selline õpetamisviis arendab mõtlemist ja analüüsivõimet (Krathwohl 2002).

\section{Uurimuse eesmärk ja hüpoteesid}

Sõnatähenduse tundmine on tähtis komponent teksti kui terviku mõistmisel. Uurimuse eesmärk oli välja selgitada muutused õpilaste sõnatähenduse tundmises Eesti üldhariduskoolide 3., 4. ja 5. klassi poiste ja tüdrukute sõnatähenduse tundmises ja teksti mõistmises. Uurimuses püstitati viis hüpoteesi:

1) õpilased, kes tunnevad sõnade tähendust paremini 3. klassis, teavad nende tähendust paremini ka 4. ja 5. klassis;

2) 3.-5. klassis tunnevad tüdrukud sõnatähendust märksa paremini kui poisid (Ning jt 2010, Prado, Plourde 2011);

3) 3.-5. klassi sõnavaraülesandes esinenud sõnade tundmine paraneb aastatega ning tüdrukud edestavad siin poisse;

4) teksti mõistmise ülesanded, mis eeldavad tekstist info äratundmise oskust, on jõukohased nii poistele kui ka tüdrukutele; seevastu soolisi erinevusi eeldati ülesandes, mis nõuab head info integreerimise oskust (Saxton 2010);

5) oletati, et õpilaste sõnatähenduse tundmine seostub tekstist arusaamisega - erinevatel kognitiivsetel tasemetel. 


\section{Meetod}

\subsection{Valim ja protseduur}

Pikiuurimuses osalesid põhikooli esimese ja teise kooliastme õpilased (3.-5. klass) 30 Eesti üldhariduskoolist. Valimi moodustamisel arvestati kooli asukohta ja piirkonda (maa-ja linnakool), kooli tüüpi (põhikool ja gümnaasium) ning klassi suurust (väikesed ja suured klassid, liitklassid). Kõik õpilased õppisid põhikooli riikliku õppekava (2007) järgi. Lapsi testiti kolme järjestikuse õppeaasta alguses. 3. klassis osales uurimuses 798 õpilast, 4. ja 5. klassis mõlemas 800 õpilast. Emakeeletestid saadeti koolidesse kinnistes ümbrikes, testi täideti emakeeleõpetajate juhendamisel eesti keele tunni ajal. Testi jaoks oli ette nähtud üks ainetund (umbes 45 minutit).

Kuna artikli autorite eesmärk oli välja selgitada pikaajalised muutused õpilaste sõnatähenduse tundmises ja teksti mõistmises, analüüsitakse järgnevalt ainult nende õpilaste vastuseid, kes sooritasid emakeeletesti kõigil kolmel aastal. Selliseid õpilasi oli kokku 508, neist $241(47,4 \%)$ poisid ja $267(52,6 \%)$ tüdrukud. Õpilaste keskmine vanus 3. klassis oli 9,08 (standardhälve 0,37); 4. klassis 10,00 aastat $(0,36)$; ja 5. klassis 10,98 aastat $(0,35)$.

\subsection{Mõõtevahendid}

Teksti mõistmist ja sõnatähenduse tundmist hinnati kolme ülesandega: 1) teksti mõistmise lihtsam ülesanne, 2) teksti mõistmise keerukam ülesanne, 3) sõnavaraülesanne. Testi väljatöötamisel võeti aluseks Bloomi hierarhilise taksonoomia edasiarendus (Krathwohl 2002), emakeele ainekava nõudmised ja riiklikud emakeele tasemetööd (Uibu jt 2010, Uibu, Tropp 2013). Kolm emakeeletesti ülesannet koostati teksti põhjal: 3. klassis oli selleks Miloš Macoureki “Kaelkirjak” (184 sõna), 4. klassis Ivan Krõlovi valmi "Haug" kohandatud versioon (161 sõna), 5. klassis sama valmi täiendatud versioon (185 sõna). Ülesannete tüübid ja tööjuhendid olid kolmel aastal samad. Õpilaste vastused kodeeriti dihhotoomselt: õige 1-ga, vale või märkimata vastus o-ga.

1. Teksti mõistmise lihtsamas ülesandes mõõdeti tekstist info leidmise ja äratundmise oskust, mis nõudis eelkõige tähelepanu ja meelespidamist. Õpilasel tuli esmalt läbi lugeda lugemispala ja seejärel otsustada, kas etteantud laused on teksti järgi õiged või väärad. Lause, mis ei vastanud teksti sisule, tuli läbi kriipsutada. 3. klassi ülesandes oli kaheksa lauset (nt Kaelkirjak ei osanud aritmeetikat. Ta nuttis palju [tekstis: ohtralt]), 4. klassis samuti kaheksa lauset (nt Haugi sü̈̈distati varguses. Rebane oli prokuröriks). 5. klassis kasutati valmi täiendatud versiooni, mis oli natuke pikem, ja ülesanne sisaldas 11 lauset (nt Kohut mõistma kutsuti ka kaks isast lammast. Kohtunikud olid targad ja õiglased). Ülesande sisereliaablus (Cronbachi alfa) oli 3. klassis 0,84, 4. klassis 0,54 ja 5. klassis 0,87.

2. Teksti mõistmise keerukamas ülesandes mõõdeti oskust integreerida ümbersõnastatud ja kontekstis sisalduvat infot. Ülesande lahendamise edukus oli seotud analüüsi-, järeldamis- ja tõlgendamisoskusega. Õpilane pidi ühendama kaks osalauset, mis kuulusid sisult kokku (nt 4. ja 5. klassis pealause: Haug anti kohtu alla, sest ...; kõrvallause: a) ta tahtis rahus surra; b) ta ei lasknud teistel 
elada; c) haug andis rebasele altkäemaksu [tekstis: pistist]). Seejuures ühildusid kõik kõrvallaused pealausega nii morfoloogiliselt kui ka süntaktiliselt. Kokku oli 3. ja 4. klassi ülesandes kuus sisult kokkukuuluvat lauset, 5. klassis seitse lauset. Ülesande sisereliaablus oli 3. klassis 0,93, 4. klassis 0,83 ja 5 . klassis 0,87 .

3. Sõnavaraülesandega hinnati õpilaste sõnatähenduse tundmise oskust. Ülesandesse valiti sõnad, mis olid teksti mõistmise seisukohalt olulised, samuti arvestati valikul sõnaliigiga (nt konkreetne ja abstraktne nimisõna, omadussõna, tegusõna, määrsõna). Õpilase ülesanne oli leida tekstis esinenud sõnadele etteantud loendist õige tähendusega sünonüüm. 3. klassi ülesanne sisaldas kolme sõna (aritmeetika, kohmakas, ohtralt), 4. klassi testis lisati neile veel kolm sõna 4. klassi tekstist (ränk, nöörima, prokurör). 5. klassi ülesandes küsiti peale 3. ja 4. klassi sõnade ka sõnu 5. klassi tekstist (pistis, noobel, valm, võlts ja kronu). Sõnu oli kokku kümme. Sõnad, mille tähendust kontrolliti kõigil kolmel aastal, olid kohmakas ja ohtralt (edaspidi: osaülesanne). Tervikülesande sisereliaablus oli 3. klassis o,62; 4. klassis 0,90 ja 5 . klassis 0,86 .

\subsection{Andmeanalüüsi meetodid}

Andmeid analüüsiti statistikapaketiga SPSS Statistics (versioon 20.0). Analüüsimisel kasutati kahesuguseid skoore. Esiteks arvutati ülesannete keskmised väärtused, kus iga õpilase keskmine väärtus märkis õigete vastuste osa kõigist võimalikest vastustest. Teiseks arvutati iga ülesande summaskoor, mida kasutati erinevuste tuvastamiseks õpilaste soo põhjal 3., 4. ja 5. klassis.

Muutuste väljaselgitamiseks õpilaste sõnatähenduse tundmises 3.-5. klassis kasutati ülesannete keskmisi väärtusi ja tehti kordusmõõtmiste dispersioonanalüüs (ingl repeated measure ANOVA). Detailseid erinevusi rühmade vahel mõõdeti post hoc-analüüsi Bonferroni testiga. Poiste ja tüdrukute erinevusi kolme aasta sõnavaraülesannetes esinenud sõnade tundmises ja teksti mõistmises hinnati ühefaktorilise dispersioonanalüüsiga (ingl one-way ANOVA), kasutades ülesannete summaskoore. Statistilise olulisuse väljendamiseks rühmade vahel kasutati peale $p$-väärtuse ka mõjufaktori suurust $\eta 2$, mille tõlgendamisel toetuti Coheni jt kriteeriumidele: $\eta 2=0,01-0,05$ nõrk mõju; $\eta 2=0,06-0,13$ keskmine mõju; $\eta 2 \geq 0,14$ suur mõju (Cohen jt 2007: 522).

Analüüsimaks õpilaste sõnatähenduse tundmise ja teksti mõistmise seoseid, kasutati Pearsoni lineaarkorrelatsiooni kordajat. Korrelatsiooni tugevuse interpreteerimisel olulisusnivool $p<0,01$ arvestati järgmisi kriteeriume: $r>0,65$ tugev seos; 0,35 < r< 0,65 mõõdukas seos; $r<0,35$ nõrk seos (Cohen jt 2007: 536-537).

\section{Tulemused}

Esmalt tehti kirjeldavad analüüsid, et selgitada muutusi õpilaste sõnatähenduse tundmises. Tervikülesande võrdlemisel kolmel aastal kasutati ülesannete keskmisi skoore. Summaskooride alusel võrreldi kolmel aastal ülesannetes esinenud sõnade tundmist. Tulemused kogu valimi ja poiste-tüdrukute kohta eraldi on esitatud tabelis 1. 
Tabel 1. Sõnavaraülesannete keskmised väärtused (M) ja standardhälbed (SD)

\begin{tabular}{|c|c|c|c|c|c|c|}
\hline \multirow{2}{*}{ Ülesanne } & \multicolumn{2}{|c|}{ Kogu valim $(N=508)$} & \multicolumn{2}{|c|}{ Poisid ( $N=241$ ) } & \multicolumn{2}{|c|}{ Tüdrukud ( $N=267$ ) } \\
\hline & $M$ & SD & $M$ & SD & $M$ & SD \\
\hline \multicolumn{7}{|l|}{ Tervikülesanne* } \\
\hline 3. klass & 0,6 & 0,33 & 0,57 & 0,34 & 0,62 & 0,32 \\
\hline 4. klass & 0,82 & 0,27 & 0,76 & 0,29 & 0,87 & 0,24 \\
\hline 5. klass & 0,56 & 0,22 & 0,53 & 0,23 & 0,59 & 0,21 \\
\hline Osaülesanne $e^{* *}$ & \multicolumn{6}{|c|}{$\max =2$} \\
\hline 3. klass & 0,92 & 0,65 & 0,86 & 0,65 & 0,97 & 0,65 \\
\hline 4. klass & 1,55 & 0,68 & 1,42 & 0,73 & 1,68 & 0,6 \\
\hline 5. klass & 1,61 & 0,61 & 1,47 & 0,65 & 1,73 & 0,54 \\
\hline
\end{tabular}

Märkus. ${ }^{*}$ keskmine skoor, ${ }^{* *}$ summaskoor

Muutust õpilaste sõnatähenduse tundmises analüüsiti 3 (ülesanne) $\times 2$ (sugu) kordusmõõtmiste dispersioonanalüüsiga. Selgus, et ajal oli statistiliselt oluline mõju tervikülesande lahendusele: $F(2,506)=192,36, p<0,001, \eta 2=0,28$. Post hoc-analüüsist selgus, et õpilaste kolme aasta tulemuste vahel oli statistiliselt oluline erinevus ( $p<0,05)$, seejuures oli kogu valimi puhul sõnatähenduse tundmine kõrgeim 4. klassis ja madalaim 5. klassis (vt tabel 1). Hüpotees, et õpilaste sõnatähenduse tundmine paraneb ajaga, leidis osaliselt kinnitust.

Õpilaste sool oli samuti oluline mõju tervikülesande sooritusele: $F(1,506)=17,33, p<0,001, \eta 2=0,03$. Post hoc-analüüs näitas, et tüdrukute tulemused olid statistiliselt oluliselt kõrgemad kui poistel kõigis klassides $(p<0,001)$. Ometi aja ja soo koosmõju tervikülesande sooritusele ei leitud, mis tähendab, et võrreldes poistega oli tüdrukute sõnatähenduse tundmine märksa parem, kuid erinevus poiste ja tüdrukute vahel ajaga ei suurenenud.

Järgnevalt uuriti poiste ja tüdrukute erinevusi kolme aasta sõnavaraülesandes küsitud sõnade tundmises. Ühefaktoriline dispersioonanalüüs näitas, et 3. klassi tekstis esinenud sõnade (kohmakas ja ohtralt) tähenduse tundmine oli tüdrukutel statistiliselt oluliselt parem kui poistel 4 . klassis $(F(1,505)=19,57, p<0,001$, $\eta 2=0,037)$ ja ka 5. klassis $(F(1,506)=12,82, p<0,001, \eta 2=0,045)$. Olulist erinevust poiste ja tüdrukute vahel ei ilmnenud 3 . klassis $(p=0,06)$.

Et hinnata erineva raskusastmega teksti mõistmise ülesannete sooritust poiste ja tüdrukute võrdluses, kasutati ülesannete summaskoore. Tabelis 2 on esitatud andmed kolme aasta ülesannete kohta.

Ühefaktorilisest dispersioonanalüüsist selgus, et teksti mõistmise lihtsamas ülesandes olid tüdrukute tulemused statistiliselt oluliselt paremad kui poistel 4. klassis $(F(1,506)=7,73, p=0,006, \eta 2=0,015)$ ja 5 . klassis $(F(1,506)=12,82$, $p<0,001, \eta 2=0,025)$. Teksti mõistmise keerukamas ülesandes edestasid tüdrukud poisse kõigil kolmel aastal: 3. klassis $F(1,501)=6,34, p=0,012, \eta 2=0,013$; 4. klassis $F(1,506)=5,02, p=0,026, \eta 2=0,01$ ja 5 . klassis $F(1,506)=11,40$, $p=0,001, \eta 2=0,022$. Selline tulemus oli kooskõlas püstitatud hüpoteesiga.

Kasutades Pearsoni lineaarkorrelatsiooni kordajat, leiti seosed õpilaste sõnatähenduse tundmise ja teksti mõistmise ülesannete keskmiste tulemuste vahel (vt tabel 3). 
Tabel 2. Teksti mõistmise ülesannete kirjeldavad näitajad: keskmised väärtused (M) ja standardhälbed (SD)

\begin{tabular}{|c|c|c|c|c|}
\hline \multirow{2}{*}{ Ülesanne } & \multicolumn{2}{|c|}{ Poisid ( $N=258$ ) } & \multicolumn{2}{|c|}{ Tüdrukud ( $\mathbf{N}=286)$} \\
\hline & M & SD & M & SD \\
\hline \multicolumn{5}{|c|}{ Teksti mõistmise lihtsam ülesanne } \\
\hline 3. klass $(\max =8)$ & 6,91 & 1,40 & 7,12 & 1,36 \\
\hline 4. klass $(\max =8)$ & 6,40 & 1,34 & 6,74 & 1,40 \\
\hline 5. klass $(\max =11)$ & 9,05 & 2,20 & 9,64 & 1,48 \\
\hline \multicolumn{5}{|c|}{ Teksti mõistmise keerukam ülesanne } \\
\hline 3. klass $(\max =6)$ & 4,85 & 1,59 & 5,18 & 1,32 \\
\hline 4. klass $(\max =6)$ & 4,07 & 1,73 & 4,41 & 1,63 \\
\hline 5. klass $(\max =7)$ & 5,54 & 1,75 & 6,03 & 1,53 \\
\hline
\end{tabular}

Tabel 3. Korrelatsioonid sõnatähenduse ja teksti mõistmise vahel

\begin{tabular}{|c|c|c|c|c|c|c|c|c|c|c|}
\hline \multicolumn{2}{|c|}{ Ülesanne } & \multicolumn{3}{|c|}{ 3. klass } & \multicolumn{3}{|c|}{ 4. klass } & \multicolumn{3}{|c|}{ 5. klass } \\
\hline \multirow{3}{*}{$\frac{\tilde{n}}{\frac{\tilde{c}}{x}}$} & $\begin{array}{l}\text { 1. Sõnatähenduse } \\
\text { tundmine }\end{array}$ & - & 2 & \multirow[t]{2}{*}{3} & \multirow{3}{*}{4} & \multirow{4}{*}{5} & \multirow{5}{*}{6} & \multirow{6}{*}{7} & \multirow{7}{*}{8} & \multirow{8}{*}{9} \\
\hline & $\begin{array}{l}\text { 2. Teksti mõistmise } \\
\text { lihtsam ülesanne }\end{array}$ & 0,2 & - & & & & & & & \\
\hline & $\begin{array}{l}\text { 3. Teksti mõistmise } \\
\text { keerukam ülesanne }\end{array}$ & 0,21 & 0,32 & - & & & & & & \\
\hline \multirow{3}{*}{$\begin{array}{l}\frac{\tilde{n}}{\tilde{x}} \\
\frac{\dot{v}}{\dot{\sigma}}\end{array}$} & $\begin{array}{l}\text { 4. Sõnatähenduse } \\
\text { tundmine }\end{array}$ & 0,31 & 0,24 & 0,4 & - & & & & & \\
\hline & $\begin{array}{l}\text { 5. Teksti mõistmise } \\
\text { lihtsam ülesanne }\end{array}$ & 0,18 & 0,24 & 0,33 & 0,39 & - & & & & \\
\hline & $\begin{array}{l}\text { 6. Teksti mõistmise } \\
\text { keerukam ülesanne }\end{array}$ & 0,16 & 0,21 & 0,29 & 0,41 & 0,33 & - & & & \\
\hline \multirow{3}{*}{$\frac{\frac{\widetilde{c}}{x}}{\frac{\pi}{\dot{n}}}$} & $\begin{array}{l}\text { 7. Sõnatähenduse } \\
\text { tundmine }\end{array}$ & 0,29 & 0,24 & 0,31 & 0,48 & 0,38 & 0,36 & - & & \\
\hline & $\begin{array}{l}\text { 8. Teksti mõistmise } \\
\text { lihtsam ülesanne }\end{array}$ & 0,22 & 0,17 & 0,31 & 0,33 & 0,38 & 0,24 & 0,41 & - & \\
\hline & $\begin{array}{l}\text { 9. Teksti mõistmise } \\
\text { keerukam ülesanne }\end{array}$ & 0,24 & 0,24 & 0,44 & 0,38 & 0,36 & 0,37 & 0,42 & 0,43 & - \\
\hline
\end{tabular}

Märkus. Tabelis esitatud väärtused on olulisusnivool $p<0,001$

Statistiliselt olulised seosed ilmnesid kõigi aastate sõnatähenduse tundmise ja teksti mõistmise ülesannete vahel. Järgnevalt esitatakse neist vaid tähtsamad. Tugevaim seos avaldus 4. ja 5. klassi sõnatähenduse tundmise vahel $(r=0,48)$. Mõnevõrra suurem korrelatsioon $(r>0,40)$ leiti 5 . klassis sõnatähenduse ja mõlema teksti mõistmise ülesande vahel ning 4. klassis sõnatähenduse ja teksti mõistmise keerukama ülesande vahel. Lisaks seostus 4. klassi sõnatähenduse tundmine mõõdukalt $(r>0,35)$ 3. klassi teksti mõistmise keerukama ja 4. klassi lihtsama ülesandega. 
Sõnatähenduse tundmine 5. klassis korreleerus mõõdukalt mõlema 4. klassi teksti mõistmise ülesandega.

Mõõdukad seosed avaldusid ka erinevate aastate teksti mõistmise ülesannete vahel. Nii korreleerus 5. klassi teksti mõistmise keerukam ülesanne sama ülesandetüübiga 3. ja 4. klassis. Lisaks leiti nii 4. klassis kui ka 5. klassis olulised seosed mõlema teksti mõistmise ülesande vahel. Seejuures oli tugevaim seos 5 . klassis $(r=0,48)$. Mõõdukalt korreleerusid ka 4. ja 5. klassi teksti mõistmise lihtsamad ülesanded (vt tabel 3).

\section{Arutelu ja järeldused}

Õpilaste üks peamisi ülesandeid põhikooli esimeses ja teises kooliastmes on omandada hea teksti mõistmise oskus (Lerkkanen 2007, Pandis 2008). Käsitletavas pikiuurimuses analüüsiti muutusi 3. -5 . klassi õpilaste sõnatähenduse tundmises ja teksti mõistmises ning hinnati nende seoseid. Nii nagu varasemates uurimustes (nt Räty jt 2004, Bray, Barron 2003), ilmnesid ka siin kõigis klassides erinevused poiste ja tüdrukute sõnatähenduse tundmises ja teksti mõistmise keerukamas ülesandes. Samuti edestasid 4. ja 5. klassis tüdrukud poisse nende sõnade tundmises, mis esinesid 3. klassi sõnavaraülesandes. Uurimusest selgus, et õpilased, kes tundsid paremini sõnade tähendust, said tekstist paremini aru. Eriti oluliseks osutus sõnatähenduse tundmine teksti mõistmise keerukama ülesande lahendamisel.

Esmalt uuriti õpilaste sõnatähenduse tundmist. Oletus, et õpilaste sõnatähenduse tundmine paraneb aastatega, leidis osaliselt kinnitust. Õpilaste sõnavaraülesande tulemused olid kõrgeimad 4. klassis, kuid langesid 5. klassis. Üks põhjuseid võib olla see, et sõnaloend, kust õpilane pidi 5. klassis valima õige tähendusega vaste, sisaldas kõige rohkem valikuid. On märgitud, et mitme valikuga ülesannetes võib valikute arv oluliselt mõjutada sooritust, sest valikute suurenedes väheneb tõenäosus vastata juhuslikult õigesti (Rodriguez 2005). Teise põhjusena on nimetatud sõnade tundmist sõnaliigiti (Saxton 2010). Kõige lihtsamini omandatakse ja teatakse konkreetse tähendusega nimisõnu, keerulisem on tegu- ja omadussõnade ning abstraktse tähendusega nimisõnade õppimine (Hirsh-Pasek, Golinkoff 2006, Imai jt 2005). Mitmes ülesandes küsitud sõnade (nt prokurör, kohmakas) tähendus võis olla õpilastele võõram, kuigi kõik sõnad pärinesid tekstist, mille laps oli läbi lugenud. Lisaks oli võimalik konteksti järgi sõnade tähendust lahti mõtestada. Kolmas põhjus võis olla õpetaja tegevus ja õpetamisviis. Praeguses uurimuses kontrolliti laste sõnatähenduse tundmist kolmel sügisel, kuid õpetaja tegevusi mõõtmiskatsete vahel ei uuritud. Sõnade tähenduse kinnistamisel on aga tähtis, et sõna kasutataks piisavalt sageli ja erinevas kontekstis (Cruse 2004, Wise jt 2010). Seepärast on vaja, et õpetaja kordaks õpilastega sõnu. Varasemate uurimuste järgi avaldab õpetaja tegevus mõju õpilaste emakeele tulemustele (Uibu jt 2010).

Analüüsides erinevusi poiste ja tüdrukute sõnatähenduse tundmises, leiti, et tüdrukute sõnavaralised teadmised olid kõigil kolmel aastal paremad kui poistel. Sellised tulemused on kooskõlas nii rahvusvahelise PISA testi kui ka riiklike tasemetööde tulemustega (Henno jt 2007, OECD 2009, 2013, Puksand jt 2010). Põhjus võib olla see, et tüdrukud erinevad poistest verbaalsetelt võimetelt, mida on peetud oluliseks teguriks sõnavara omandamisel ja sõnade tähenduse eristamisel 
(Saxton 2010). Samas ei leitud praeguses uurimuses aja ja soo koosmõju õpilaste sõnatähenduse tundmisele. Järelikult, tüdrukute ja poiste sõnavarateadmistes ilmnevad erinevused, kuid aastatega need ei suurene.

Varem õpitud sõnade tundmist kontrolliti kahe sõnaga (kohmakas ja ohtralt), mis esinesid sõnavaraülesandes kolmel aastal. Selgus, et 3. klassis ei olnud poiste ja tüdrukute teadmistes erinevusi, kuid 4. ja 5. klassis oli tüdrukute sooritus oluliselt parem kui poistel. Et mõista sõnade kohmakas ja ohtralt tähendust, pidi laps aru saama lause sisust. Arvestades, et põhikoolis on tüdrukute vaimne areng poiste omast kiirem (Logan, Johnston 2010, Ning jt 2010), on mõistetav, miks varem tekstis esinenud sõnade tundmine valmistas poistele hiljem raskusi. Lisaks, sõnade abstraktne tähendus võis olla takistuseks nende omandamisel (Hall, Sabey 2007, Saxton 2010).

Toetudes Krathwohli (2002) seisukohtadele, oletati, et teksti mõistmise keerukama ülesandega, mis nõudis oskust integreerida ümbersõnastatud infot, tulevad tüdrukud paremini toime kui poisid. Teises teksti mõistmise ülesandes, mis eeldas info äratundmise oskust, soolisi erinevusi ei oodatud. Ootuspäraselt ilmneski, et kui 3. klassis oli teksti mõistmise lihtsam ülesanne jõukohane nii poistele kui ka tüdrukutele, siis keerukama ülesandega, kus laps pidi ühendama kaks osalauset, arvestades kontekstis sisalduvat infot, tulid tüdrukud poistest paremini toime kõigil kolmel aastal. Varasemates uurimustes on leitud, et teksti mõistmist hõlbustab erinevate süntaktiliste ja grammatiliste konstruktsioonide tundmine (Cain, Oakhill 2007) ning võime infot töödelda ja ekstrapoleerida (Krathwohl 2002). Näib, et esimeses ja teises kooliastmes on tüdrukutel need oskused paremini arenenud.

Viimasena uuriti seoseid õpilaste sõnatähenduse tundmise ja teksti mõistmise vahel. Ilmnes, et õpilased, kes tundsid 4. klassis paremini sõnade tähendust, lahendasid 5. klassis paremini nii sõnatähenduse kui ka teksti mõistmise ülesandeid. Olulised seosed leiti ka 4. klassi sõnatähenduse ja 3. klassi teksti mõistmise keerukama ülesande vahel. Niisiis, lapsed, kes said 3. klassis teksti mõistmise keerukama ülesandega paremini hakkama, näitasid järgmisel aastal paremaid teadmisi sõnatundmises. Lisaks avaldus oluline seos 4. klassi sõnatähenduse ja teksti mõistmise lihtsama ülesande vahel. Samuti tundsid 5. klassis paremini sõnade tähendust õpilased, kellel teksti mõistmise mõlema ülesande sooritus oli 4. klassis parem. Sellest võib järeldada, et sõnavaralised teadmised on määrav tegur teksti mõistmisel. Sõnade tähendust tundmata ei ole võimalik mõista lausete tähendust ning teksti kui terviku sisu (Karlep 2003).

Olulised seosed leiti ka erinevate aastate teksti mõistmise lihtsama ja keerukama ülesande vahel. Õpilased, kes said 3. klassis teksti mõistmise keerukama ülesandega paremini hakkama, lahendasid selle paremini ka 4. ja 5. klassis. Teksti mõistmise hierarhilist iseloomu on märkinud Zhang jt (2008). Teises kooliastmes saavutavad teksti mõistmises paremaid tulemusi õpilased, kellel on need oskused välja arenenud esimeses kooliastmes.

Analüüsides teksti mõistmise lihtsama ja keerukama ülesande seoseid aastate kaupa, selgus, et 5. klassis saavutasid paremad tulemused teksti mõistmise keerukamas ülesandes õpilased, kes said paremini hakkama ka lihtsama ülesandega. Sarnane seos teksti mõistmise ülesannete vahel leiti ka 4. klassis. On selge, et kui õpilane mõistab teksti sisu, siis ei valmista talle raskusi tekstist info äratundmine ega ka ümbersõnastatud ja kontekstist tuleneva info seostamine (Krathwohl 2002). 
Praegusel uurimusel olid mõned piirangud, mida tuleks tulemuste üldistamisel arvesse võtta. Esiteks, 3. klassi testis ning 4. ja 5. klassi testis kasutati erinevaid lugemispalasid. Teiseks, ülesannete tüübid ja tööjuhendid olid kõigil aastatel samad, kuid sõnade arv sõnavaraülesannetes oli erinev. On märgitud, et mitme valikuga ülesannetes võib valikute arv mõjutada ülesande sooritust (Rodriguez 2005). Peale valikute arvu tuleks sõnavaraülesannete koostamisel arvestada ka seda, et sõnatähendus on kontekstitundlik. Kolmandaks, uurimuses ei hinnatud selliseid sõnatähenduse tundmist ja teksti mõistmist mõjutavaid tegureid nagu õpilase lugemise täpsus ja motivatsioon ning õpetaja tegevused jmt. Suurem tunnuste variatiivsus võimaldanuks saada mitmekesisema pildi õpilaste sõnatähenduse tundmist ja teksti mõistmist mõjutavatest teguritest põhikoolis.

Ometi saab uurimuse kestuse (kolm aastat) ja esindusliku valimi põhjal teha järeldusi esimese ja teise kooliastme õpilaste sõnatähenduse tundmise ja teksti mõistmise kohta. Esiteks, teksti mõistmine ja sõnatähenduse tundmine on omavahel seotud ning sõnade tähendus kontekstitundlik. Teiseks, tüdrukud edestavad poisse nii sõnatähenduse tundmises kui ka teksti mõistmises. Kolmandaks, tüdrukud teavad poistest paremini varem õpitud sõnade tähendusi. Järelikult tuleks poiste sõnavara arengu ja tekstimõistmise oskuse toetamiseks arvestada nende keelelist arengut ja pakkuda neile võimete ja huvide kohaseid tekste.

\section{Viidatud kirjandus}

Begeny, John C.; Silber, Jennifer M. 2006. An examination of group-based treatment packages for increasing elementary-aged students' reading fluency. - Psychology in the Schools, 43 (2), 183-195. http://dx.doi.org/10.1002/pits.20138

Block, Cathy C.; Pressley, Michael 2002. What comprehension instruction could be. M. Pressley, C. C. Block (Eds.). Comprehension Instruction. New York: Guilford, 383-392.

Bloem, Ineke; La Heij, Wido 2003. Semantic facilitation and semantic interference in word translation: Implications for models of lexical access in language production. Journal of Memory and Language, 48 (3), 468-488. http://dx.doi.org/10.1016/ So749-596X(02)00503-X

Bock, Kathryn J. 1982. Toward a cognitive psychology of syntax: Information processing contributions to sentence formulations. - Psychological Review, 89 (1), 1-47. http:// dx.doi.org/10.1037/0033-295X.89.1.1

Bray, Gayle Babbitt; Barron, Sheila 2003. Assessing reading comprehension: The effects of text-based interest, gender, and ability. - Educational Assessment, $9(3-4), 107-128$.

Broek, Paul van den; Espin, Christine A. 2012. Connecting cognitive theory and assessment: Measuring individual differences in reading comprehension. - School Psychology Review, 41 (3), 315-325.

Bruemmer, Katherine Hlavach 2006. Teaching to biological gender preferences in an all-boys Catholic school. - English Journal, 95 (6), 31-41. http://dx.doi.org/10.2307/30046625

Butterworth, Brian 1989. Lexical access in speech production. - W. Marslen (Ed.). Wilson Lexical Representation and Process. Cambridge, MA: MIT Press.

Cain, Kate; Oakhill, Jane; Bryant, Peter 2004. Children's reading comprehension ability: Concurrent prediction by working memory, verbal ability, and component skills. - Journal of Educational Psychology, 96 (1), 31-42. http://dx.doi. org/10.1037/0022-0663.96.1.31

Cain, Kate; Oakhill, Jane 2007. Reading comprehension difficulties: Correlates, causes, and consequences. - Kate Cain, Jane Oakhill (Eds.). Children's Comprehension Problems 
in Oral and Written Language: A Cognitive Perspective. New York, London: The Guilford Press, 41-76.

Caramazza, Alfonzo 1997. How many levels of processing are there in lexical access? - Cognitive Neuropsychology, 14 (1), 177-208. http://dx.doi.org/10.1080/026432997381664

Chomsky, Noam 1965. Aspects of the Theory of Syntax. MIT Press.

Chun, Christian W. 2009. Critical literacies and graphic novels for English-language learners: Teaching maus. - Journal of Adolescent \& Adult Literacy, 53 (2), 144-153. http:// dx.doi.org/10.1598/JAAL.53.2.5

Cohen, Louis; Manion, Lawrence; Morrison, Keith 2007. Research Methods in Education. 6th ed. London, New York: Routledge.

Corthals, Paul 2010. Nine- to twelve-year olds'metalinguistic awareness of homonymy. International Journal of Language \& Communication Disorders, 45 (1), 121-128. http://dx.doi.org/10.3109/13682820902745446

Cruse, Alan D. 2004. Meaning in Language: An Introduction to Semantics and Pragmatics. Oxford: Oxford University Press.

Eason, Sarah H.; Goldberg, Lindsday F.; Young, Katherine M.; Geist, Megan C.; Cutting, Laurie E. 2012. Reader-text interactions: How differential text and question types influence cognitive skills needed for reading comprehension. - Journal of Educational Psychology, 104 (3), 515-528. http://dx.doi.org/10.1037/aoo27182

Hall, Kendra M.; Sabey, Brenda L. 2007. Focus on the facts: Using informational texts effectively in early elementary classrooms. - Early Childhood Education Journal, 35 (3), 261-268. http://dx.doi.org/10.1007/s10643-007-0187-2

Henno, Imbi; Tire, Gunda; Lepmann, Tiit; Reiska, Priit; Ehala, Martin 2007. Ülevaade rahvusvahelise õpilaste õpitulemuslikkuse hindamise programmi PISA 2006 tulemustest. [The Official Review of Students Results of PISA 2006.] http://uuringud. ekk.edu.ee/fileadmin/user_upload/documents/PISA_l6pparuanne_041207.pdf (5.5.2013).

Hirsh-Pasek, Kathy; Golinkoff, Roberta M. (Eds.) 2006. Action Meets Words: How Children Learn Verbs. Oxford: Oxford University Press. http://dx.doi.org/10.1093/acprof: oso/9780195170009.001.0001

Häkkinen, Kaisa 2007. Keeleteaduse alused. [Basics of Linguistics.] Tallinn: AS Pakett.

Imai, Mutsumi; Okada, Hiroyuki; Haryu, Etsuko 2005. Mapping novel nouns and verbs onto dynamic action events: Are verb meanings easier to learn than noun meanings for Japanese children? - Child Development, 76 (2), 340-355. http://dx.doi. org/10.1111/j.1467-8624.2005.00849_a.x

Kabilan, Muhammad Kamarul; Seng, Mak Kem; Kee, Ooi Ae 2010. Reader-text transaction in text comprehension. - Journal of Language Studies, 10 (3), 127-142.

Karlep, Karl 2003. Kõnearendus. Emakeele abiõpe II. [Tutoring Native Language II.] Tartu: Tartu Ülikooli Kirjastus.

Kelley, Michelle J.; Decker, Emmeline O. 2009. The current state of motivation to read among middle school students. - Reading Psychology, 30 (5), 466-485. http://dx.doi. org/10.1080/02702710902733535

Krathwohl, David R. 2002. A Revision of Bloom's Taxonomy: An Overview. - Theory into Practice, 41 (4), 212-218. http://dx.doi.org/10.1207/s15430421tip4104_2

Lenneberg, Eric H. 1967. Biological Foundations of Language. Oxford: Wiley.

Lerkkanen, Marja-Kristiina 2007. Lugema õppimine ja õpetamine alus- ja algõpetuses. [Teaching and Learning How to Read in Pre- and Primary-Education.] Tartu: Tartu Ülikooli Kirjastus.

Logan, Sarah; Johnston, Rhona 2010. Investigating gender differences in reading. - Educational Review, 62 (2), 175-187. http://dx.doi.org/10.1080/00131911003637006 
Masterson, Julie J.; Apel, Kenn 2006. Effect of modality on spelling words varying in linguistic demands. - Developmental Neuropsychology, 29 (1), 261-277. http://dx.doi. org/10.1207/s15326942dn2901_13

Mayberry, Rachel I. 1993. First-language acquisition after childhood differs from secondlanguage acquisition: The case of American sign language. - Journal of Speech and Hearing Research, 36 (6), 1258-1270. http://dx.doi.org/10.1044/jshr.3606.1258

Meisel, Jurgen M. 2008. Child second language acquisition or successive first language acquisition? - B. Haznedar, E. Gavruseva (Eds.). Current Trends in Child Second Language Acquisition. A Generative Perspective. Amsterdam: Benjamins, 55-80.

Müürsepp, Mare 1986. Lasteraamatu keel kasvatusmõjurina. [The Language of Children's Books in the Impact of Education.] - L. Talts (toim.). Algõpetuse aktuaalseid probleeme II. [Actual Problems in Pre-Education II.] Tallinn: TPÜ Kirjastus, 99-111

Ning, Hailiang; Dai, Xue; Zhang, Fachun 2010. On gender difference in English language and its causes. - Asian Social Science, 6 (2), 126-130.

OECD 2009. Creating effective teaching and learning environments: First results from TALIS. Paris: OECD. http://www.oecd.org/education/school/43023606.pdf (14.4.2013).

OECD 2013. PISA 2012 Results: Ready to Learn - Students' Engagement, Drive and Self- Beliefs (Volume III). Pisa: OECD Publishing. http://dx.doi.org/10.1787/9789264201170-en

Pandis, Meeli 2002. Lugemisoskus ja sellega seotud tegurid. [Reading Ability and Related Factors.] Magistritöö. Tallinn: TPÜ kasvatusteaduste teaduskond.

Pandis, Meeli (koost.) 2008. 3. klassi eesti keele ja vene keele tasemetöö analüüs. http:// www.ekk.edu.ee/vvfiles/o/3_kl_eesti_ja_vene_keele_tasemetoo_analyys_2008. $\operatorname{pdf}(30.4 .2013)$.

Pečjak, Sonja; Podlesek, Anja; Pirc, Tina 2011. Model of reading comprehension for 5 th grade students. - Studia Psychologica, 53 (1), 53-67.

PISA $=$ The Programme for International Student Assessment. [Rahvusvaheline õpilaste õpitulemuslikkuse hindamisprogramm.] http://www.oecd.org/pisa/ (14.2.2014).

Prado, Ludivina; Plourde, Lee A. 2011. Increasing reading comprehension through the explicit teaching of reading strategies: Is there a difference among the genders? - Reading Improvement, 48 (1), 32-43.

Primor, Liron; Pierce, Margaret E.; Katzir, Tami 2011. Predicting reading comprehension of narrative and expository texts among Hebrew-speaking readers with and without a reading disability. - Annals of Dyslexia, 61, 242-268. http://dx.doi.org/10.1007/ s11881-011-0059-8

Puksand, Helin; Henno, Imbi; Lepmann, Tiit 2010. Pisa 2009 - Eesti tulemused. [Pisa 2009Estonian results.] G. Tire (toim.). http://www.ekk.edu.ee/vvfiles/o/PISA_2009_Eesti. pdf (28.4.2013).

Põhikooli ja gümnaasiumi riiklik õppekava 2007. Vabariigi Valitsuse 25. jaanuari 2002. a määrus nr 56. https://www.riigiteataja.ee/akt/12888846 (20.3.2013).

Põhikooli riiklik õppekava 2010. Vabariigi Valitsuse 28. jaanuari 2010. a määrus nr 14. https://www.riigiteataja.ee/akt/13273133 (15.4.2013).

Rodriguez, Michael C. 2005. Three options are optimal for multiple-choice items: A metaanalysis of 80 years of research. - Educational Measurement: Issues and Practice, 24 (2), 3-13. http://dx.doi.org/10.1111/j.1745-3992.2005.00006.x

Räty, Hannu; Kasanen, Kati; Kiiskinen, Johanna; Nykky, Merja 2004. Learning intelligence - children's choices of the best pupils in the mother tongue and mathematics. - Social Behavior and Personality, 32 (3), 303-312. http://dx.doi.org/10.2224/ sbp.2004.32.3.303

Saxton, Matthew 2010. Child Language. Acquisition and Development. SAGE Publications. Schroeder, Sascha 2011. What readers have and do: Effects of students' verbal ability and reading time components on comprehension with and without text availability. - Journal of Educational Psychology, 103 (4), 877-896. http://dx.doi.org/10.1037/aoo23731 
Soalt, Jennifer 2005. Bringing together fictional and informational texts to improve comprehension. - The Reading Teacher, 58 (7), 680-683. http://dx.doi.org/10.1598/ RT.58.7.8

Soodla, Piret; Vija, Maigi; Pajusalu, Renate 2013. Eesti ja soome sõnalugemistestide võrdlus. [Comparison of Estonian and Finnish word reading tests.] - Eesti Rakendusligvistika Ühingu aastaraamat, 9, 279-296. http://dx.doi.org/10.5128/ERYa9.18

Zhang, Lawrence Jun; Gu, Peter Yongqi; Hu, Guangwei 2008. A cognitive perspective on Singaporean primary school pupils' use of reading strategies in learning to read in English. - British Journal of Educational Psychology, 78 (2), 245-271. http://dx.doi. org/10.1348/000709907X218179

Tomasello, Michael; Akhtar, Nameera; Dodson, Kelly; Rekau, Laura 1997. Differential productivity in young children's use of nouns and verbs. - Journal of Child Language, 24 (2), 373-387. http://dx.doi.org/10.1017/So305000997003085

Tulving, Endel; Madigan, Stephen A. 1970. Memory and verbal learning. - Annual review of Psychology, 21, 437-484. http://dx.doi.org/10.1146/annurev.ps.21.020170.002253

Uibu, Krista; Kikas, Eve; Tropp, Kristiina 2010. Teaching practices, their dynamics, associations with self-reported knowledge and students' language achievement. - A. Toomela (Ed.). Systemic Person-Oriented Study of Child Development in Early Primary School. Frankfurt am Main: Peter Lang Verlag, 47-71.

Uibu, Krista; Voltein, Elve 2010. Eesti keel. [Estonian language.] - E. Kikas (toim.). Õppimine ja õpetamine esimeses ja teises kooliastmes. [Learning and Teaching in the First and Second Stage of Primary School.] Tallinn: Eduko, 215-242

Uibu, Krista; Tropp, Kristiina 2013. Longitudinal study of the development of language competence among the Estonian 4th and 5th grade students. - J. Mikk, P. Luik, M. Veisson (Eds.). Change in Teaching and Learning. Frankfurt am Main: Peter Lang Verlag, 45-63.

Wise, Justin C.; Sevcik, Rose A.; Morris, Robin D.; Lovett, Maureen W.; Wolf, Maryanne; Kuhn, Melanie; Meisinger, Beth; Schwanenflugel, Paula 2010. The relationship between different measures of oral reading fluency and reading comprehensionin second-grade students who evidence different oral reading fluency difficulties. Language, Speech, and Hearing Services in Schools, 41, 340-348. http://dx.doi. org/10.1044/0161-1461(2009/08-0093)

Krista Uibu (Tartu Ülikool) peamine uurimisvaldkond on laste keeleline areng ja õpetajate õpetamistegevuste mõju õpilaste keelepädevustele.

Salme 1a, 51013 Tartu, Estonia

krista.uibu@ut.ee

Maile Timm (Kõrveküla lasteaed), uurimisvaldkond on õpilaste sõnasemantika areng põhikoolis. Lasteaia 4, 60512 Tartu vald, Estonia timmmaile@gmail.com 


\section{WORD SEMANTICS AND TEXT COMPREHENSION IN THE FIRST AND SECOND STAGE OF THE PRIMARY SCHOOL}

\section{Krista Uibu, Maile Timm}

Univerity of Tartu, Preschool of Kõrveküla

Word recognising is important to understand the text. When the meaning of the word does not fix in the memory then text comprehension might became a problem for a student in all school stages. The aim of the present longitudinal study was to find out to what extent student word recognition and text comprehension changes in primary school's first and second stage. The article analyses student word recognition and two different level text comprehension tasks in Grades 3 to 5.508 students (267 girls and 241 boys) from 30 schools participated in this study. The research revealed that students who knew the meaning of different words better also had better text comprehension skills. In gender comparison, girls outperformed boys in word recognition and higher-level text comprehension task, which requires the ability to integrate information in all three consecutive years. Girls also outperformed boys in previously learned word recognition. To support students' word semantic and text comprehension skills it is necessary to take into consideration students' developmental differences and offer them age-appropriate texts.

Keywords: word recognition, text comprehension, gender differences, longitudinal study, Estonian 